УДК 553.98:556.3 (571.511)

\title{
ПРОГНОЗ НЕФТЕГАЗОНОСНОСТИ ЮРСКИХ И ПАЛЕОЗОЙСКИХ ОТЛОЖЕНИЙ ЮЖНЫХ РАЙОНОВ ЗАПАДНО-СИБИРСКОГО БАССЕЙНА
}

\author{
Садыкова Яна Владиславовна', \\ sadykovaYV@ipgg.sbras.ru \\ Фомин Михаил Александрович ${ }^{1,2}$ \\ FominMA@ipgg.sbras.ru \\ Рыжкова Светлана Владимировна',2, \\ RizhkovaSV@ipgg.sbras.ru \\ Новиков Дмитрий Анатольевич ${ }^{1,2}$, \\ NovikovDA@ipgg.sbras.ru \\ Дульцев Федор Федорович', \\ DultsevFF@ipgg.sbras.ru

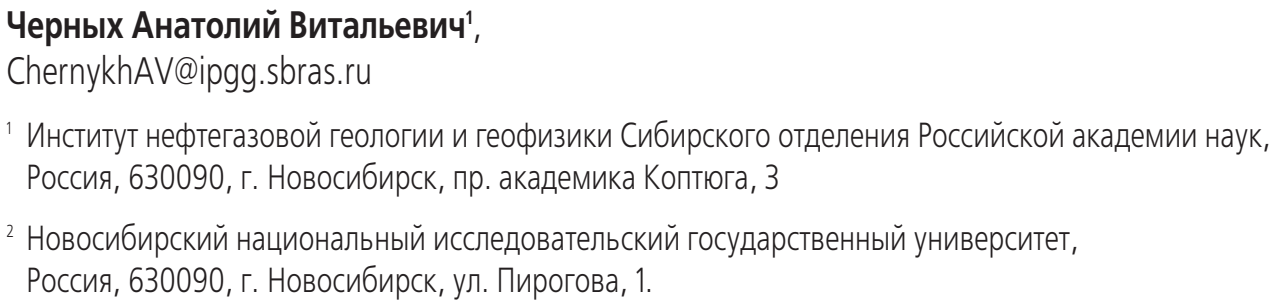

Статья посвящена перспективам нефтегазоносности палеозойских и мезозойских комплексов в южных районах Западной Сибири. Для региона характерны сложнопостроенные неантиклинальные ловушки, связанные с полифациальным генезисом вмещающих толщ, особенностями тектонического и литологического строения. В связи с этим выявление перспективных земель для поисков залежей углеводородов невозможно без применения комплексного подхода, включающего геологические, литологические, тектонические и гидрогеологические исследования. Использование гидрогеологических критериев нефтегазоносности основано на ведущей роли подземных вод в процессах генерации, миграции и аккумуляции углеводородов. В процессе исследования установлены гидрогеохимические особенности подземных вод, выделены гидрогеохимические аномалии, тесно связанные с залежами углеводородов (I, B, Br, $\mathrm{NH}_{4}$ и др.). Охарактеризованы генетические типы подземных вод и степень их катагенетической преобразованности. Приведены основные результаты палеогидрогеохимических и палеогидродинамических реконструкций, выделены зоны нефтегазообразования и нефтегазонакопления, показаны возможные пути латеральной и вертикальной миграции флюидов. Изучены особенности геологического строения, выделены зоны развития улучшенных коллекторов. Совместное использование гидрогеологических и геологических показателей продуктивности недр позволило обосновать набор критериев нефтегазоносности, несколько различных для палеозойского, среднеюрского и верхнеюрского комплексов. С помощью предложенного комплекса критериев был осуществлен прогноз нефтегазоносности и оконтурены участки различных категорий перспективности (высокоперспективные, перспективные и земли с неясными перспективами, требующие дальнейшего изучения). Применение данного подхода будет способствовать локализации геологоразведочных работ и повысит эффективность геофизических методов при поиске новых залежей углеводородов в южных районах Западно-Сибирского бассейна.

\section{Ключевые слова:}

Южные районы Западно-Сибирского бассейна, гидрогеология, гидрогеохимия,

нефтегазоносносность, верхнеюрский, нижне-среднеюрский и палеозойский водоносные комплексы

\section{Введение}

Проблема выявления новых залежей нефти и газа в южных районах Западно-Сибирского бассейна связана со сложным строением коллекторов, флюидоупоров и их приуроченностью к сложнопостроенным неантиклинальным ловушкам, для выделения которых необходимо использование комплексного подхода к прогнозированию, включающему как литологические, тектонические, палеогеографические, так и гидрогеологические методы исследования.

В регионе открыто 21 месторождение (15 нефтяных, 5 нефтегазоконденсатных и 1 газоконден- сатное) (рис. 1). Всего выявлено порядка 40 залежей, сосредоточенных в юрских и палеозойских отложениях. В пределах верхнеюрского комплекса в процессе испытания скважин установлено большое количество признаков углеводородов (пленки и притоки нефти, газа и конденсата) в пределах площадей, где залежи еще не выявлены.

По оценкам Института нефтегазовой геологии и геофизики Сибирского отделения Российской академии наук (ИНГГ СО РАН) исследуемый регион перспективен для прироста запасов углеводородов: многие месторождения нуждаются в доразведке и разработке с помощью новых технологий. 
Нефть некоторых месторождений близка по своим качествам к марке Brent, характеризуется высоким качеством и минимальным количеством примесей.

В настоящее время наблюдается снижение объемов геологоразведочных работ, при этом, например, за 2016 г. в Новосибирской области добыча нефти также упала на 30 \%. Выявление перспективных земель для поисков новых залежей углеводородов позволит локализовать геологоразведочные работы и будет способствовать повышению экономической эффективности нефтепоисковых работ.

\section{Объект исследования}

В южных районах Западной Сибири перспективы нефтегазоносности в основном связаны с верхнеюрскими (верхняя подсвита васюганской свиты), среднеюрскими (тюменская свита), палеозойскими отложениями и их зоной контакта - НГГЗК (нефтегазоносный горизонт зоны контакта палеозоя и мезозоя).

Доюрское основание в регионе представлено разновозрастными образованиями палеозоя и триaca [1]. На большей части территории триасовые отложения имеют локальное распространение и в строении доюрского основания играют подчиненную роль. Отложения палеозоя сильно дислоцированы, а органическое вещество в них находится на высоких стадиях катагенеза. Палеозойские залежи сконцентрированы в двух типах коллекторов: коренных карбонатных породах палеозоя и в кремнисто-глинистых породах коры выветривания (нефтегазоносный горизонт зоны контакта НГГЗК) [2]. Притоки нефти из внутрипалеозой- ских резервуаров были получены на Малоичском, Нижнетабаганском, Северо-Калиновом, Южно-Табаганском и Южно-Тамбаевском месторождениях.

В отложениях НГГЗК открыты залежи на Восточном, Калиновом, Северо-Калиновом, Солоновском, Урманском и Южно-Тамбаевском месторождениях. Все залежи пространственно тяготеют либо к зонам улучшенных коллекторов, сформировавшихся в результате гидротермальной проработки, либо к корам химического выветривания карбонатных и вулканогенно-осадочных пород. Все выявленные в НГГЗК залежи характеризуются крайне сложным геологическим строением, обусловленным складчато-блоковой тектоникой, неравномерностью литологического состава пород и их коллекторских свойств, что существенно усложняет прогноз новых месторождений.

Нижнеюрские отложения как самостоятельный объект поисков залежей нефти и газа не рассматриваются, поскольку в исследуемом регионе распространены фрагментарно. В пределах большей части юга Западной Сибири отложения средней юры представлены преимущественно континентальной тюменской свитой. Промышленные скопления углеводородов в отложениях средней юры выявлены на Калиновом, Кулгинском, Нижнетабаганском, Северо-Калиновом, Смоляном и Широтном месторождениях. Наличие большого количества результатов испытаний скважин позволяет дополнительно выделить перспективные объекты для поисков залежей углеводородов.

Верхнеюрский комплекс в Новосибирской области изучен наиболее полно. Его проницаемая часть представлена продуктивным горизонтом $Ю_{1}$, входящим в состав оксфордского водоносного го-

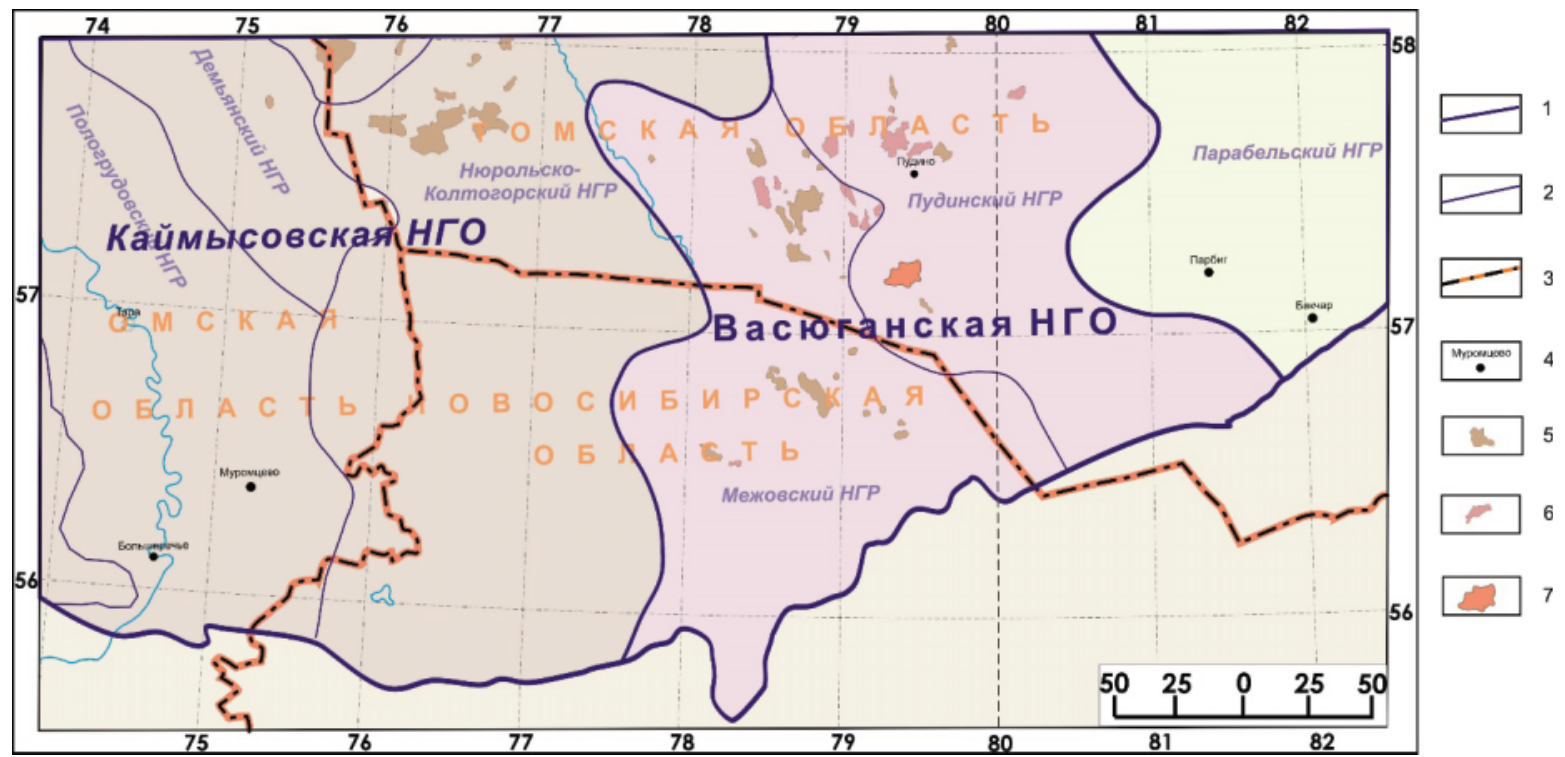

Pис. 1. Обзорная карта южных районов Западно-Сибирского бассейна (по материалам ИНГГ СО РАН). Границы: 1 - нефтегазоносных областей; 2 - нефтегазоносных районов; 3 - административные; 4 - населенные пункты; месторождения: 5 - нефтяные, 6 -нефтегазоконденсатные, 7 - газовые и газоконденсатные

Fig. 1. Overview map of the southern areas of the West Siberian basin (on materials IPGG SB RAS). Borders: 1 - oil-and-gas areas; 2 - oil-andgas regions; 3 -administrative; 4 -settlements; fields: 5 -oil, 6 -oil-gas-condensate, 7 - gas and gas-condensate 
ризонта. Региональным перекрывающим флюидоупором служит георгиевская, баженовская и куломзинская свиты, объединяемые в кимериджсковаланжинский водоупорный горизонт. В настоящее время в пределах верхнеюрского комплекса открыты залежи на таких месторождениях, как Арчинское, Верх-Тарское, Тай-Дасское и многих других.

В последние десятилетия повышенный интерес геологов во всем мире связан с изучением черносланцевых толщ. Наиболее важными направлениями изучения таких пород с точки зрения нетрадиционных коллекторов с трудноизвлекаемыми запасами являются исследования их литологии, геохимии и коллекторских свойств [3-8]. В Западно-Сибирском нефтегазоносном бассейне также распространена черносланцевая формация - баженовская свита, которая последние годы активно изучается и рассматривается как самостоятельный объект для поисков в ней скоплений углеводородов $[9,10]$. Современные геологические материалы позволяют рассматривать баженовскую свиту и в исследуемом регионе в качестве перспективного комплекса. В настоящий момент доказана промышленная нефтеносность баженовский свиты на Федюшкинском и Снежном месторождениях Томской области [11].

В пределах исследуемого региона выделяются несколько основных нефтепроизводящих толщ юрского и палеозойского возраста. Изучение состава нефтей палеозойского комплекса [12] позволило выделить два типа нефтепроизводящих пород. $\mathrm{K}$ первому следует отнести аномально обогащенные органическим веществом морские производящие толщи палеозойского возраста. Содержания органического углерода в девонских отложениях колеблется от 0,03 до $3 \%$, максимальные концентрации отмечены в аргиллитах. В кембрийских породах концентрация органического углерода варьируется от 0,07 до 0,38 \% [12, 13]. Степень катагенетической преобразованности органического вещества палеозойских отложений, определенная по отражательной способности витринита, $-\mathrm{MK}_{2}-\mathrm{AK}_{3}$ [14]. Источником нефтей второго типа являются континентальные нефтематеринские породы озерно-болотного и болотного генезиса, их состав близок к составу битумоидов тогурской свиты [12]. Это подтверждает наличие процессов миграции углеводородов из нижне-среднеюрских отложений в палеозойские коллекторы. Содержание органического углерода в тогурской свите колеблется от 0,09 до 7,55 \%. Степень его катагенетической преобразованности отвечает стадиям катагенеза $\mathrm{MK}_{1}{ }^{2}-\mathrm{MK}_{2}$ [14]. Кроме того, существуют нефти промежуточного типа, которые сформировались в результате смешения первых двух на стадии аккумуляции углеводородов [12].

Основным источником углеводородов в регионе считается баженовская свита (волжский ярус). Для оценки масштабов и времени генерации углеводородов в ней на изучаемой территории бы- ло проведенное двумерное математическое моделирование. Толщина свиты в среднем составляет 25 м, а концентрация органического углерода изменяется от 4 до $12 \%$. Подстилающая ее георгиевская свита (верхи оксфордского-низы волжского ярусов) имеет мощность 8-10 м. В верхней части ее разреза содержание органического углерода изменяется от 1,2 до 2,7 \%, что дает основание рассматривать верхи георгиевской свиты также в качестве нефтематеринской формации. Результаты моделирования зафиксировали, что нефтематеринские свиты вошли в главную зону нефтеобразования в конце палеогена. Из органического вещества баженовской свиты образовалось в три раза больше жидких углеводородов, чем из органического вещества георгиевской свиты. В процессе катогенетического преобразования пород в юрских отложениях наблюдалось постоянное увеличение палеотемператур, что способствовало активному протеканию процессов генерации и миграции углеводородов. $\mathrm{K}$ раннеолигоценовому времени температуры достигли $100{ }^{\circ} \mathrm{C}$.

\section{Методика исследований}

Применение гидрогеологических исследований для поисков нефти и газа основано на ведущей роли водных растворов в процессах нефтегазообразования и нефтегазонакопления. Длительное время подобные исследования проводятся во многих осадочных бассейнах Австралии, Дании, Канады, Китая, Норвегии, России, США и других стран, что способствовало разработке многочисленных гидрогеологических показателей продуктивности недр [15-29]. Наиболее информативными являются гидрохимические и палеогидрогеологические [16]. Поскольку строение коллекторов как в верхнеюрском, так и в нижне-среднеюрском и палеозойском комплексах имеет сложное строение, использование комплексного подхода к прогнозированию полностью оправдано.

Строение палеозойских залежей очень сложное - они приурочены к тектонически и литологическим экранированным ловушкам, выявление которых усложняется меньшей степенью изученности глубоким бурением. Несмотря на длительное изучение, не существует общепринятой методики выделения перспективных объектов для поисков углеводородов. Одним из основных геологических критериев остается состав слагающих пород фундамента, поэтому выделение зон с улучшенными коллекторскими свойствами является первоочередной задачей. Подобная карта была составлена в ИНГГ СО РАН на основе изучения данных глубокого бурения, структурных, палеоструктурных карт и сейсмических разрезов [2]. Анализ состава пород фундамента в комплексе с гидрогеологическими и палеогидрогеологическими данными позволяет выделить участки, наиболее перспективные для поисков углеводородов.

Среднеюрские отложения (тюменская свита) на сводах и поднятиях имеют, как правило, сокра- 
щённую мощность, пониженные коллекторские и экранирующие свойства. Проведенные исследования показывают, что благоприятными зонами для формирования залежей нефти и газа в среднеюрских отложениях являются прогибы, впадины и их склоны, где увеличиваются мощности и качество коллекторов и экранирующих толщ. Наибольшие перспективы связаны с литологическими ловушками, сформированными в аллювиальных обстановках. Русла палеорек, особенно меандрирующих, обладают повышенными коллекторскими свойствами, они имеют рукавообразные (шнурковые) морфологические формы в плане и изолированы алевритисто-глинистыми осадками, сформированными в пойменных и болотных обстановках [30]. В связи с этим для прогноза благоприятных зон основное значение имеют палеогеографические и палеогидрогеологические исследования [21]. Для понимания процессов миграции и аккумуляции углеводородов необходимо знание морфологии и пространственного размещения областей сноса и накопления осадочного материала, распределение фациальных обстановок и выявления зон внутреннего питания и разгрузки подземных вод. Анализ палеогеографических реконструкций Западно-Сибирского бассейна на байос-батское время позволил выявить в регионе зоны развития русловых и дельтовых фаций, характеризующихся улучшенными коллекторскими свойствами [31]. Интерпретация каротажных материалов дала возможность оконтурить участки максимальной песчанистости тюменской свиты, наиболее благоприятные для размещения залежей углеводородов.

Большинство открытых месторождений в оксфордском резервуаре верхнеюрского комплекса приурочено к локальным поднятиям, они достаточно надежно выделяются по данным сейсморазведки [32]. В настоящее время основные перспективы связывают с неантиклинальными ловушками, для выявления зон распространения которых требуется более детально рассмотреть пространственное расположение зон аккумуляции и генерации углеводородов, наметить пути их миграции.

Для оценки перспектив нефтегазоносности баженовской свиты были оценены условия, наиболее благоприятные для накопления углеводородов и сохранения залежей. Наиболее важными являются толщины баженовского горизонта и экранирующие свойства флюидоупоров - подачимовской толщи и георгиевской свиты. Кроме того, учитывалось содержание органического углерода, степень зрелости органического вещества и современные геотермические условия $[10,13,14,33]$.

Изучение особенностей микрокомпонентного состава подземных вод нижнего водоносного этажа южных районов Западно-Сибирского бассейна показало, что в контурных зонах залежей углеводородов происходит увеличение содержания многих микрокомпонентов: йода, брома, бора, кремнезема, аммония, лития, рубидия, цинка, марганца, стронция и многих других (табл. 1). Помимо этого важным индикатором наличия залежи также является возрастание коэффициента $\mathrm{B} / \mathrm{Br}$, общей газонасыщенности, содержания гомологов метана, средние значения общей минерализации и степень метаморфизации подземных вод. Таким образом, анализ гидрогеохимических данных и результатов испытания подземных вод позволил обосновать комплекс гидрогеохимических критериев, благоприятных для наличия залежей углеводородов в изучаемом регионе.

таблииа. Среднее содержание микроэлементов в водах ареальной зоны залежей углеводородов и в непродуктивных пластах нижнего водоносного этажа южных районов Западно-Сибирского бассейна

Table. $\quad$ Average content of microcomponents in waters of areal zone of hydrocarbon deposits and in unproductive layers of the ground water-bearing floor of the southern regions of the West Siberian basin

\begin{tabular}{|c|c|c|c|c|c|c|c|c|c|}
\hline \multirow{2}{*}{$\begin{array}{l}\text { Комплекс } \\
\text { Complex }\end{array}$} & \multirow{2}{*}{$\begin{array}{l}\text { Флюиды } \\
\text { Fluids }\end{array}$} & I & $\mathrm{SiO}_{2}$ & $\mathrm{NH}_{4}$ & $\mathrm{Li}$ & $\mathrm{Rb}$ & $\mathrm{Zn}$ & $\mathrm{Mn}$ & \multirow{2}{*}{ ตั } \\
\hline & & \multicolumn{7}{|c|}{$\mathrm{M \Gamma} / \mathrm{дM}^{3} / \mathrm{mg} / \mathrm{l}$} & \\
\hline \multirow{2}{*}{$\begin{array}{l}\text { Верхнеюрский } \\
\text { Upper Jurassic }\end{array}$} & Воды/Water & 5,4 & 32,5 & 43,7 & 4,4 & 0,4 & 0,1 & 1,3 & 0,2 \\
\hline & $\begin{array}{l}\text { Углеводороды } \\
\text { Hydrocarbons }\end{array}$ & 6,9 & 35,3 & 60,2 & 5,2 & 0,6 & 1,4 & 1,7 & 0,4 \\
\hline \multirow{2}{*}{$\begin{array}{l}\text { Нижне-сред- } \\
\text { неюрский } \\
\text { Lower-Middle } \\
\text { Jurassic }\end{array}$} & Воды/Water & 5,0 & 28,6 & 38,9 & 6,7 & 0,4 & 0,5 & 0,4 & 0,1 \\
\hline & $\begin{array}{l}\text { Углеводороды } \\
\text { Hydrocarbons }\end{array}$ & 8,7 & 34,0 & 68,5 & 7,2 & 0,7 & 0,5 & 0,6 & 0,3 \\
\hline \multirow{2}{*}{$\begin{array}{c}\text { Палеозойский } \\
\text { Paleozoic }\end{array}$} & Воды/Water & 9,4 & 28,0 & 46,6 & 5,1 & 0,9 & 0,4 & 1,5 & 0,1 \\
\hline & $\begin{array}{l}\text { Углеводороды } \\
\text { Hydrocarbons }\end{array}$ & 11,1 & 40,3 & 82,1 & 6,1 & 1,0 & 1,1 & 1,8 & 0,3 \\
\hline
\end{tabular}

В качестве критериев для прогноза нефтегазоносности предлагается использовать комплекс геологических, гидрогеохимических и палеогидрогеологических показателей. К прямым гидрогеохимическим показателям относится газовый, микрокомпонентный состав подземных вод и водорастворенного органического вещества. $К$ прямым геологическим - наличие залежей нефти или признаки углеводородов, полученные в процессе испытания скважин. $K$ косвенным показателям отнесены общие геологические, палеогидродинамические, палеогидрогеохимические критерии.

Основными критериями оценки перспектив нефтегазоносности по палеогидрогеологическим данным являются: количество и длительность элизионных и инфильтрационных этапов в истории развития бассейна; удаленность от зоны внешнего питания подземных вод (инфильтрации); выделение зон внутреннего питания и разгрузки подземных вод и определение возможных путей миграции флюидов.

\section{Результаты и их обсуждение}

В начале гидрогеологической истории развития бассейна в течение триасового периода и ранне-среднеюрской эпохи преобладающим режимом был инфильтрационный. В это время господствовал континентальный режим осадконакопления, активно шли эрозионные процессы и формировались коры выветривания на останцах палеозойско- 
го фундамента. Инфильтрация пресных вод атмосферного генезиса способствовала улучшению коллекторских свойств палеозойских пород. Процессы осадконакопления начались в раннем тоаре. Повышение уровня моря и региональная трансгрессия привела к образованию в пределах крупных впадин озерных и ингрессивно-морских глинистых отложений тогурской свиты, разделенных обширными участками денудационной равнины [28]. В аален-байосское время осадконакопление имело также мозаичный характер, тяготело к погруженным участкам рельефа, преобладающими обстановками были денудационная и аккумулятивные озерно-аллювиальная и прибрежная равнины. Миграция подземных вод атмосферного генезиса происходила от зон питания, расположенных в пределах возвышенных структур рельефа, к зонам разгрузки, тяготеющим к отрицательным структурным элементам. Основными зонами питания являлись останцы палеозойского питания, возвышающиеся в пределах положительных тектонических структур - Межовского структурного мегамыса, Тебисско-Воробьевского структурного мегамыса, Северо-Межовской мегамоноклинали и др. Зонами разгрузки являлись наиболее погруженные участки в пределах Колтогорско-Нюрольского желоба, Кыштовского наклонного мезопрогиба, Бакчарской мезовпадины и др.

Начавшаяся в бате региональная трансгрессия привела к установлению морского режима седиментации в регионе. Далее захоронение сингенетичных вод шло совместно с морскими талассогенными осадками в бассейне с соленостью от 20 до 35 г/дм ${ }^{3}$ [28]. Таким образом, после образования мощного водоупорного кимериджско-валанжинского горизонта возраста залегающие ниже юрские и палеозойский комплексы развивались как единая элизионная система. Только в пределах Барабинско-Пихтовой мегамоноклизы могли протекать процессы инфильтрации атмосферных вод. Это является важным условием образования и сохранения залежей углеводородов.

Проведение палеогидродинамических реконструкций показало, что области внутреннего питания подземных вод (палеопьезомаксимумы) в юрское время располагались в пределах наиболее погруженных частей Бакчарской мезовпадины, центральной и восточной частей Барабинско-Пихтовой мегамоноклизы, Колтогорско-Нюрольского желоба, Кыштовского наклонного мезопрогиба, Межовского структурного мегамыса, Муромцевско-Сидельниковского прогиба и Парабельского наклонного мегавала. Областями скрытой разгрузки (палеопьезминимумами) являлись поднятия и их борта, расположенные в пределах западной части Барабинско-Пихтовой мегамоноклизы, Верхневасюганской антеклизы, Пудинского куполовидного мезоподнятия и зоны сочленения СевероМежовской мегамоноклинали с Межовским структурным мегамысом. Латеральная миграция флюидов происходила от внутренних зон питания к зо- нам скрытой разгрузки под действием разности геостатических нагрузок.

Основным поставщиком подземных вод для нижне-среднеюрского и верхнеюрского комплексов являлся кимериджско-валанжинский водоупорный горизонт, по мере погружения и уплотнения глинистых осадков происходило выделение больших объемов элизионных вод. Детальные расчеты позволили численно охарактеризовать палеогидродинамические зоны. В пределах внутренних областей питания подземных вод в сумме отжималось от 50 до $80 \mathrm{млн} \mathrm{M}^{3} / \mathrm{\kappa M}^{2}$, в областях скрытой разгрузки -до $35 \mathrm{млн} \mathrm{m}^{3} / \mathrm{\kappa M}^{2}$. Переходные земли были отнесены к транзитной области, в пределах которой происходила латеральная миграция флюидов от зон питания (генерации углеводородов) к зонам скрытой разгрузки (аккумуляции). При наличии благоприятных литологических условий в транзитной области могли располагаться вторичные зоны питания и разгрузки. Полученные результаты позволили выделить обширную зону питания подземных вод в центральной части региона, протягивающуюся с юго-запада на северо-восток. Основные зоны разгрузки выявлены в пределах Останинской, Тай-Дасской, Межовской, Веселовской, Урманской и ряда других площадей.

Помимо латеральной миграции, немаловажную роль играют процессы вертикальной миграции флюидов в вышезалегающие комплексы и подток из нижележащих горизонтов по зонам тектонических нарушений. Анализ мезозойско-кайнозойских тектонических процессов позволил выделить три этапа формирования разрывных нарушений: раннеюрский, берриас-валанжинский и посттуронский (кайнозойский). В ранней юре и аалене палеозойские блоки фундамента имели тенденцию к росту, что сформировало и обновило приуроченные к ним разломы, как правило затухающие в базальной части осадочного чехла [34]. Картирование этих разломов важно для изучения процессов миграции флюидов в пределах нижнесреднеюрского и палеозойского комплексов. Берриас-аптские разломы не могли служить каналами миграции углеводородов, поскольку к моменту вступления баженовской свиты в главную зону нефтегазообразования были уже «залечены». Тем не менее они могли быть экранами для верхнеюрских залежей углеводородов. Формирование кайнозойских разломов совпало со временем вхождения баженовской свиты в НГГЗК, они могли служить каналами для миграции углеводородов. Однако в пределах юго-восточных районов ЗападноСибирского бассейна дизъюнктивная тектоника имеет подчиненное значение из-за низкой тектонической активности в меловое и кайнозойское время [34].

Изучение особенностей химического состава подземных вод и рассолов южных районов Западно-Сибирского бассейна показало, что в пределах нижнего водоносного этажа распространены преимущественно соленые воды и рассолы с величиной 
общей минерализации от 7,5 до 87,0 г/дм ${ }^{3}$ (фоновое значение - 55-60 г/дм³ ) хлоридного натриевого состава, также встречаются хлоридные кальцевые и хлоридные кальциево-натриевые (по классификации С.А. Щукарева). По генетическому типу преобладают седиментогенные и древние инфильтрогенные, смешанные в различной степени между собой. Вблизи контуров углеводородных залежей локально развиты конденсатогенные воды, генетически связанные с ними [15-17, 35]. Подземные воды всех изучаемых комплексов находятся на начальной стадии метаморфизации химического состава, не зависимо от состава вмещающих пород [36]. Отношение $\mathrm{rNa} / \mathrm{rCl}$ колеблется от 0,1 до 1,8 ; $\mathrm{Ca} / \mathrm{Cl}$ от 0,01 до 0,2 , a $\mathrm{r}\left(\mathrm{HCO}_{3}+\mathrm{CO}_{3}\right) / \mathrm{r}(\mathrm{Ca}+\mathrm{Mg})$ coставляет 0,01-4,0 [35].

Анализ микрокомпонентного состава подземных вод, водорастворенного органического вещества и газов показал, что вблизи контуров залежей в значительной степени возрастают концентрации генетически связанных с ОВ элементов: йода, бора, брома, аммония, тяжелых углеводородов, бензола, фенола, органических соединений и щелочных элементов [15-17]. В пределах изучаемых комплексов выявлены и оконтурены гидрогеохимические аномалии по содержанию (мг/дм $\left.{ }^{3}\right): \mathrm{I}>10$ $(\mathrm{Pz}>25), \quad \mathrm{Br}>100 \quad(\mathrm{Pz}>150), \mathrm{B}>20, \quad \mathrm{NH}_{4}>100$ $(\mathrm{Pz}>150), \mathrm{SiO}_{2}>100, \mathrm{Rb}>1, \mathrm{Sr}>450, \mathrm{Zn}>0,8, \mathrm{Mn}>1$, $\mathrm{Li}>7$. Большинство аномалий приурочено к локальным поднятиям с выявленными залежами углеводородов [37].

Наибольшие концентрации йода установлены на Арчинской, Герасимовской, Калиновой и других площадях, бора - на Большереченской, Малоичской, Ракитинской, Тай-Дасской и других площадях, брома - на Верх-Тарской, Крыловской, Нижне-Табаганской и других площадях. Максимальные содержания аммония характерны для Восточно-Герасимовской, Калиновой, Крыловской, Останинской и др. площадей.

Среди щелочных элементов наибольшие концентрации рубидия выявлены на Арчинской, Кулгинской, Останинской и Южно-Тамбаевской площадях. Повышенные содержания лития отмечаются на Кенгской, Останинской, Урманской и др. площадях. Среди щелочноземельных элементов аномальные значения стронция отмечены на Верхне-Комбарской, Герасимовской, Калиновой, Крыловской, Останинской, Северо-Останинской, Тамбаевской и Урманской площадях. Максимальные концентрации цинка выделяются на Верхне-Комбарской, Нижне-Тамбаевской, Тамбаевской и Урманской площадях, марганца - на Игольской, Калиновой, Нижне-Табаганской, Северо-Останинской и Урманской площадях.

В пределах палеозойского гидрогеологического комплекса в составе водорастворенных газов преобладает метан, среднее содержание которого составляет 87,8 об. \% . Средние концентрации (об. \%) $\mathrm{CO}_{2}-6,29, \mathrm{~N}_{2}-3,59, \mathrm{H}_{2}-0,56$ и $\mathrm{He}-0,04$. В нижне-среднеюрском комплексе отмечаются более высокие концентрации азота, достигающие 9,6 об. \% , содержания углекислого газа более низкие $\left(1,21\right.$ об. \%), содержания $\mathrm{H}_{2}$ и Не аналогичные палеозойскому. Превалирующим также остается метан $(80,5$ об. \%). В составе водорастворенных газов верхнеюрского комплекса основным компонентом, аналогично с нижележащими, является метан. Средние концентрации (об. \%) $\mathrm{CO}_{2}$ составляют $1,10, \mathrm{~N}_{2}-8,57, \mathrm{H}_{2}-0,19$ и $\mathrm{He}-0,03$. На ряде продуктивных площадей (Калиновая, НижнеТабаганская, Останинская и др.) во всех комплексах сумма гомологов метана превышает $5 \%$.

Исходя из приведенной выше информации, установленной в ходе исследования и взятой из опубликованных материалов, были составлены схемы перспектив нефтегазоносности по каждому комплексу, что позволило выделить продуктивные участки и ранжировать земли по категориям. Всего было выделено три категории перспективности для поисков новых залежей углеводородов: высокоперспективные, перспективные и земли с неясными перспективами, требующие дополнительного изучения.

В пределах палеозойского комплекса высокоперспективные земли характеризуются:

1) приуроченностью к положительным структурно-тектоническим элементам, сложенным карбонатными или глинисто-кремнистыми породами;

2) получением притоков или признаков наличия углеводородов в результате испытания скважин, повышенным газовым фактором;

3) средней минерализацией и низкой метаморфизацией подземных вод, наличием прямых гидрогеохимических показателей нефтегазоносности;

4) существенным преобладанием в составе водорастворенных газов метанового типа с высоким содержанием тяжелых углеводородов.

5) наличием дизьюнктивных нарушений и приуроченностью к зонам скрытой разгрузки подземных вод.

Вторая категория - перспективные земли, характеризуются теми же параметрами. Нефтегазоносность в пределах таких земель не доказана, но по прямым гидрогеохимическим показателям высока вероятность наличия залежей углеводородов. К третьей категории, земли с неясными перспективами, относятся участки, в пределах которых нефтегазоносность не выявлена, степень их изученности глубоким бурением низкая, гидрогеохимическое опробование в скважинах не проводилось. Тем не менее геологические и палеогидрогеологические исследования показывают наличие условий, благоприятных для формирования и сохранения залежей нефти и газа. Требуется дальнейшее более детальное изучение глубоким бурением палеозойских интервалов разреза.

Итоговая карта прогноза перспектив нефтегазоносности палеозойского комплекса характеризует пространственное расположение земель различной 


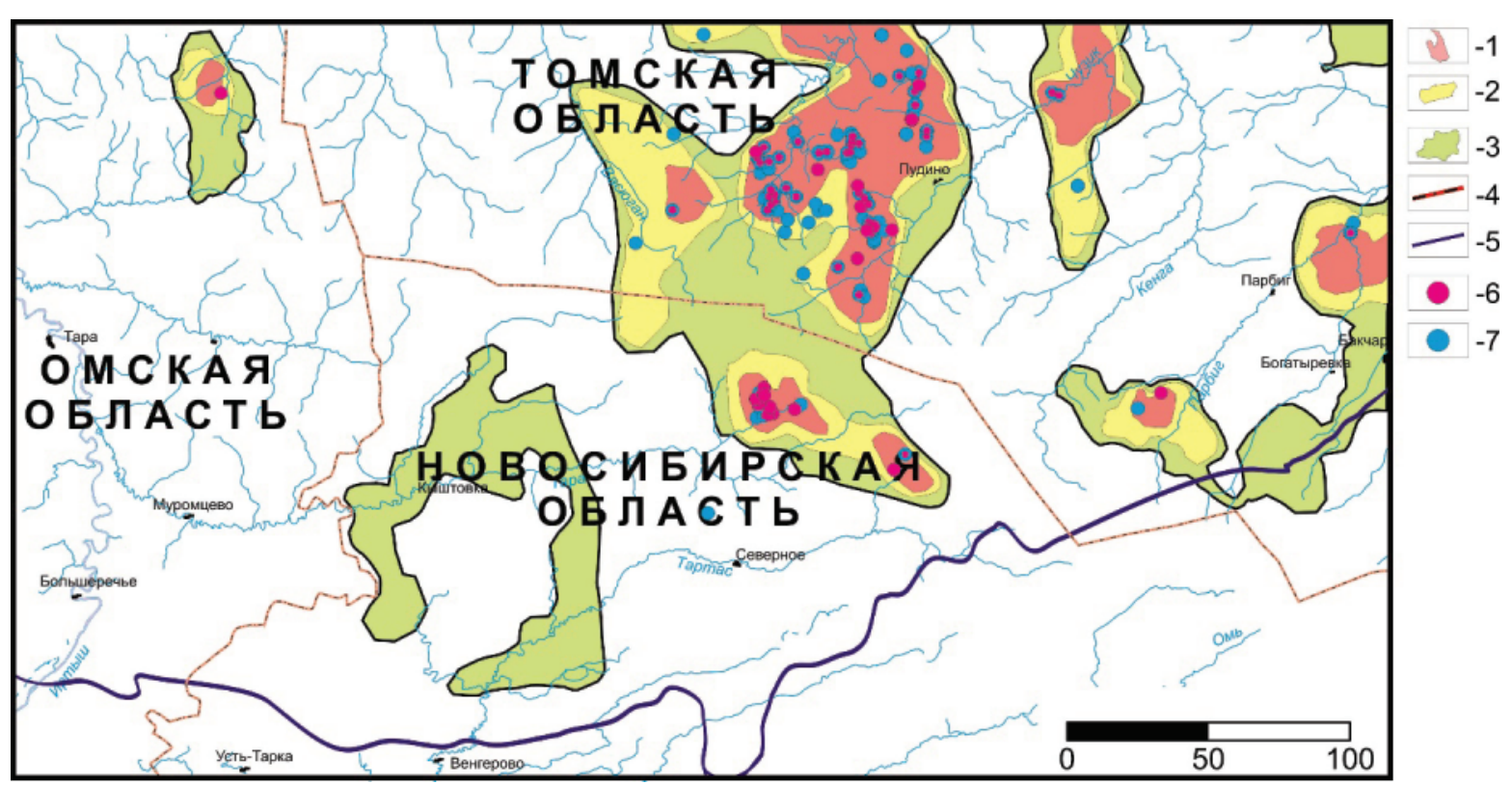

Pис. 2. Схема прогноза нефтегазоносности палеозойского колплекса южных районов Западно-Сибирского бассейна. Условные обозначения: категории перспективности земель для поисков углеводородов: 1 - высокоперспективные, 2 - перспективные, 3 - зелли с неясныли перспективали, требующие дополнительного изучения; границы: 4 - адлинистративные, 5 - Западно-Сибирской нефтегазоносной провиниии; скважины с: 6 - полученныли притокали углеводородов; 7 - выявленными гидрогеохиическили аномалияли

Fig. 2. Scheme of forecasting oil-and-gas content of a Paleozoic complex in southern regions of the West Siberian basin. Symbols: categories of prospects of lands for search of hydrocarbons: 1 - highly-perspective, 2 - perspective, 3 -lands without clear prospects demanding additional studying; borders: 4 - administrative, 5 - West Siberian oil-and-gas province; wells with: 6 - received inflows of hydrocarbons; 7 - revealed hydrogeochemical anomalies

перспективности (рис. 2). Опираясь на перечисленные критерии, было выделено восемь зон, высокоперспективных для поиска новых залежей углеводородов или уточнения контуров уже установленных промышленных скоплений нефти и газа.

Для нижне-среднеюрского комплекса (тюменская свита) высокоперспективные земли обладают следующими особенностями:

1) приуроченностью к зонам с улучшенными коллекторскими свойствами тюменской свиты (мощности песчаной части разреза превышают $50 \mathrm{M})$;

2) выявленением в пределах данных участков зоны развития русловых фаций в байос-батское время;

3) установленными притоками или признаками наличия углеводородов, полученными в результате испытания скважин, повышенным газовым фактором;

4) средней минерализацией и низкой метаморфизацией подземных вод, наличием прямых гидрогеохимических показателей нефтегазоносности;

5) существенным преобладанием метанового типа с высоким содержанием тяжелых углеводородов в составе водорастворенных газов.

6) приуроченностью к зонам транзита и/или разгрузки подземных вод.

Перспективные земли и земли с неясными перспективами были выделены по такому же принципу, как и в палеозойском комплексе (рис. 3). Поскольку степень гидрогеохимической изученности и опробования комплекса намного ниже, чем палеозойского, детальность прогноза существенно снижается. Выделено четыре высокоперспективные зоны, при этом площадь перспективных земель и земель с неясными перспективами существенно расширяется.

В пределах верхнеюрского комплекса (оксфордского горизонта) высокоперспективные земли отличаются:

1) установленными притоками или признаками наличия углеводородов, полученными в результате испытания скважин, повышенным газовым фактором;

2) средней минерализацией и низкой метаморфизацией подземных вод, наличием прямых гидрогеохимических показателей нефтегазоносности;

3) существенным преобладанием метанового типа с высоким содержанием тяжелых углеводородов в составе водорастворенных газов;

4) приуроченностью к зонами внутренней разгрузки флюидов и наличием зоны питания подземных вод на ближайшем расстоянии;

5) незначительной мощностью георгиевского горизонта (менее $10 \mathrm{~m}$ ), не препятствовавшего миграции флюидов из баженовской нефтематеринской толщи.

Основываясь на представленные критерии, выделено одиннадцать высокоперспективынх зон для поиска новых залежей углеводородов (рис. 4). 


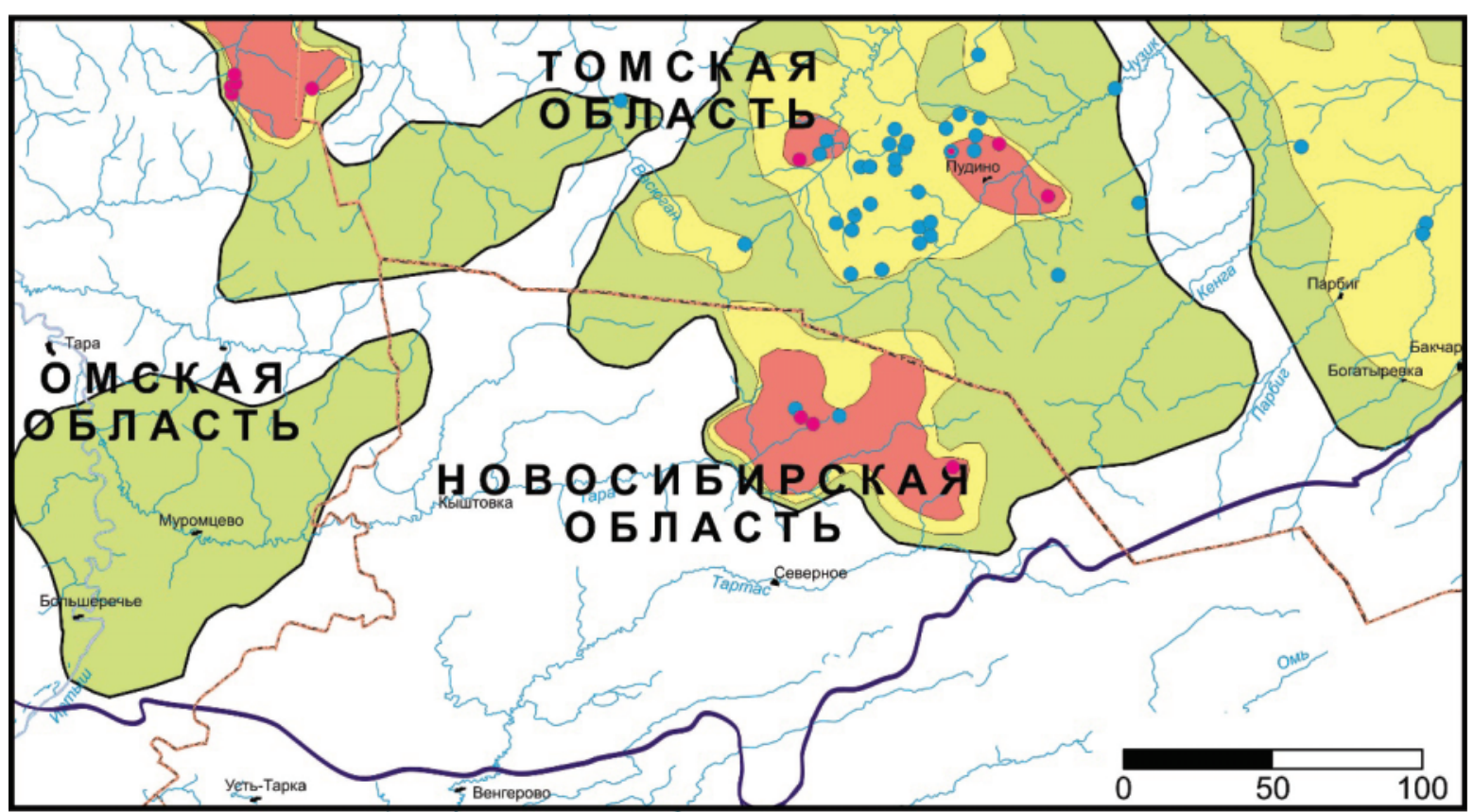

Рис. 3. Схема прогноза нефтегазоносности среднеюрских отложений южных районов Западно-Сибирского бассейна. Условные обозначения см. рис. 2

Fig. 3. Scheme of forecasting oil-and-gas content of Middle Jurassic deposits in southern regions of the West Siberian basin. Symbols see in Fig. 2

В пределах перспективных и земель с неясными перспективами также возможно открытие новых залежей, но требуются более детальные исследования и дополнительное изучение геологического строения.
Интерес в отношении нефтеносности в изучаемом районе также представляет баженовская свита. Анализ новых аналитических геохимических данных по керну с учетом результатов испытаний скважин и данных ГИС позволил авторам предло-

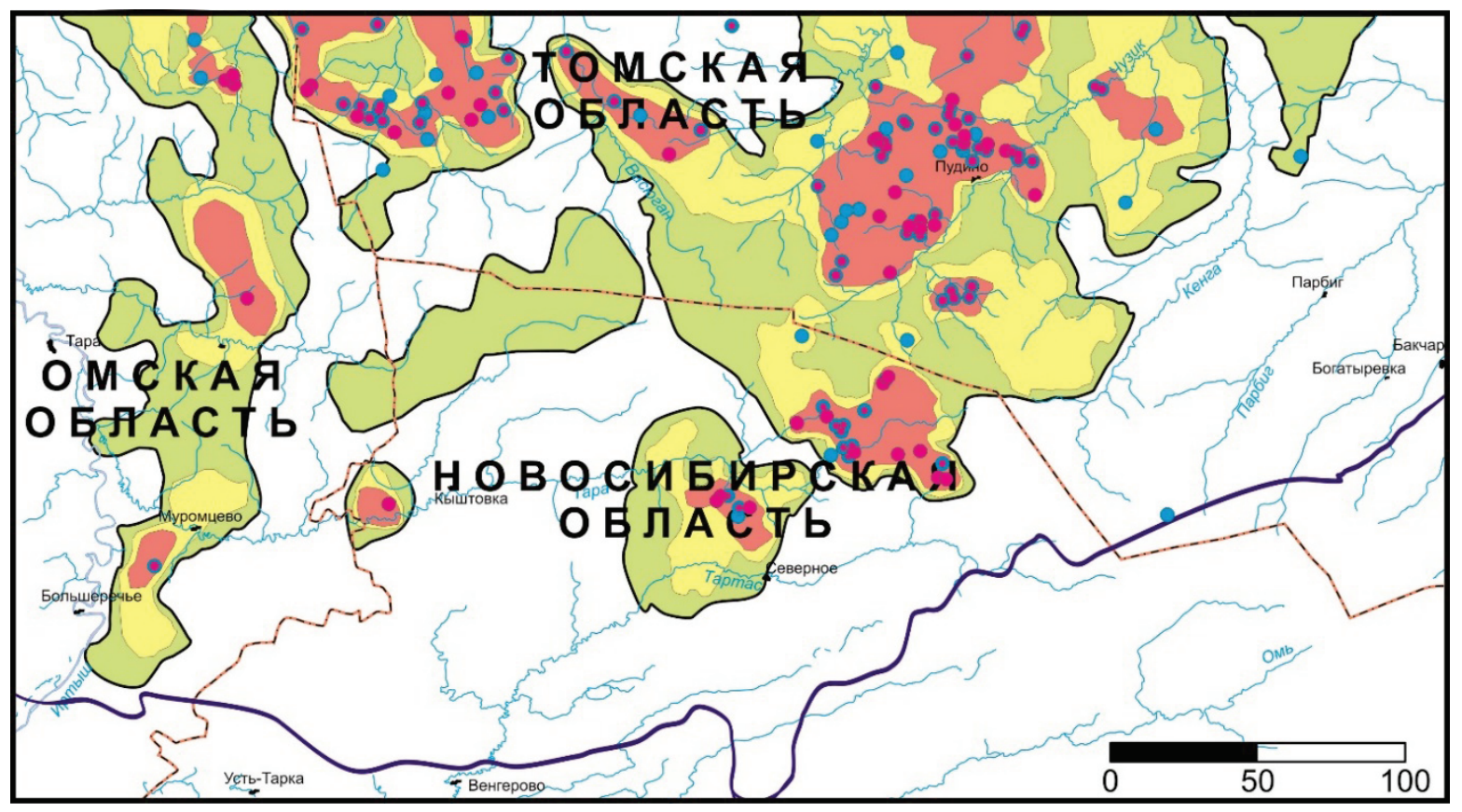

Puc. 4. Схема прогноза нефтегазоносности верхнеюрского колплекса (без баженовского горизонта) южных районов Западно-Сибирского бассейна. Условные обозначения сл. рис. 2

Fig. 4. Scheme of forecasting oil-and-gas content of Upper Jurassic complex (without the bazhenov formation) of the West Siberian basin southern regions. Symbols see in Fig. 2 
жить свою оценку региональных перспектив нефтеносности баженовской свиты в Межовском НГР.

На юго-западе Томской области (рис. 5) получены притоки нефти из баженовской свиты на Федюшкинской, Глуховской, Западно-Квензерской и др. площадях. Основой для выделения послужили следующие критерии:

1) притоки нефти из баженовской свиты на Федюшкинской, Глуховской, Западно-Квензерской и др. площадях были получены в зонах с толщинами георгиевской свиты 4 м и более. Такие толщины нижележащего флюидоупора являются достаточными для консервации жидких углеводородов в баженовской свите;

2) органическое вещество преобразовано до стадии $\mathrm{MK}_{2}$ [38];

3) толщины баженовской свиты с современным содержанием органического углерода от 7 до $10 \%$ [39] достигают $15 \mathrm{~m}$;

4) современные температуры в кровле юры превышают $90^{\circ} \mathrm{C}$.

Перспективные земли характеризуются следующими геологическими параметрами:

1) толщины георгиевской свиты превышают $10 \mathrm{M}$

2) органическое вещество преобразовано до стадии $\mathrm{MK}_{1}^{2}[38]$;

3) толщины баженовской свиты с современным содержанием органического углерода от 7 до $10 \%$ превышают 5 м при общей толщине свиты около 20 м [40].

В пределах перспективных земель в скважине Ракитинская-4 (Новосибирская область) получен приток нефти $1,6 \mathrm{~m}^{3} /$ сут из приподошвенной части баженовской свиты.
В качестве земель с неясными перспективами, требующими дополнительного изучения, рассматриваются земли, в пределах которых органическое вещество баженовской свиты находится в главной фазе нефтеобразования [38]. Требуется дальнейшее геологическое изучение этих территорий и получение нового фактического материала.

Таким образом, наиболее перспективной с точки зрения нефтеносности баженовской свиты являются юго-западные районы Томской области. Рекомендуется провести испытания баженовской свиты на Межовской площади, а также новые испытания на Ракитинской площади на севере Новосибирской области. На этих участках также могут быть открыты промышленные скопления нефти в баженовской свите.

\section{Выводы}

В южных районах Западно-Сибирского бассейна залежи, приуроченные к антиклинальным ловушкам верхнеюрского комплекса, открыты и эксплуатируются длительное время. Для воспроизводства минерально-сырьевой базы необходимо выявление новых залежей в сложнопостроенных неантиклинальных ловушках и слабоизученных палеозойском и среднеюрском комплексах. Для выявления подобных залежей необходимо применение комплексного подхода к прогнозированию, включающему помимо традиционных геологических критериев гидрогеологические и палеогидрогеологические.

Различные подходы, предложенные для палеозойского, среднеюрского и верхнеюрского комплексов, позволяют выделить зоны, наиболее благоприятные для проведения дальнейших геолого-

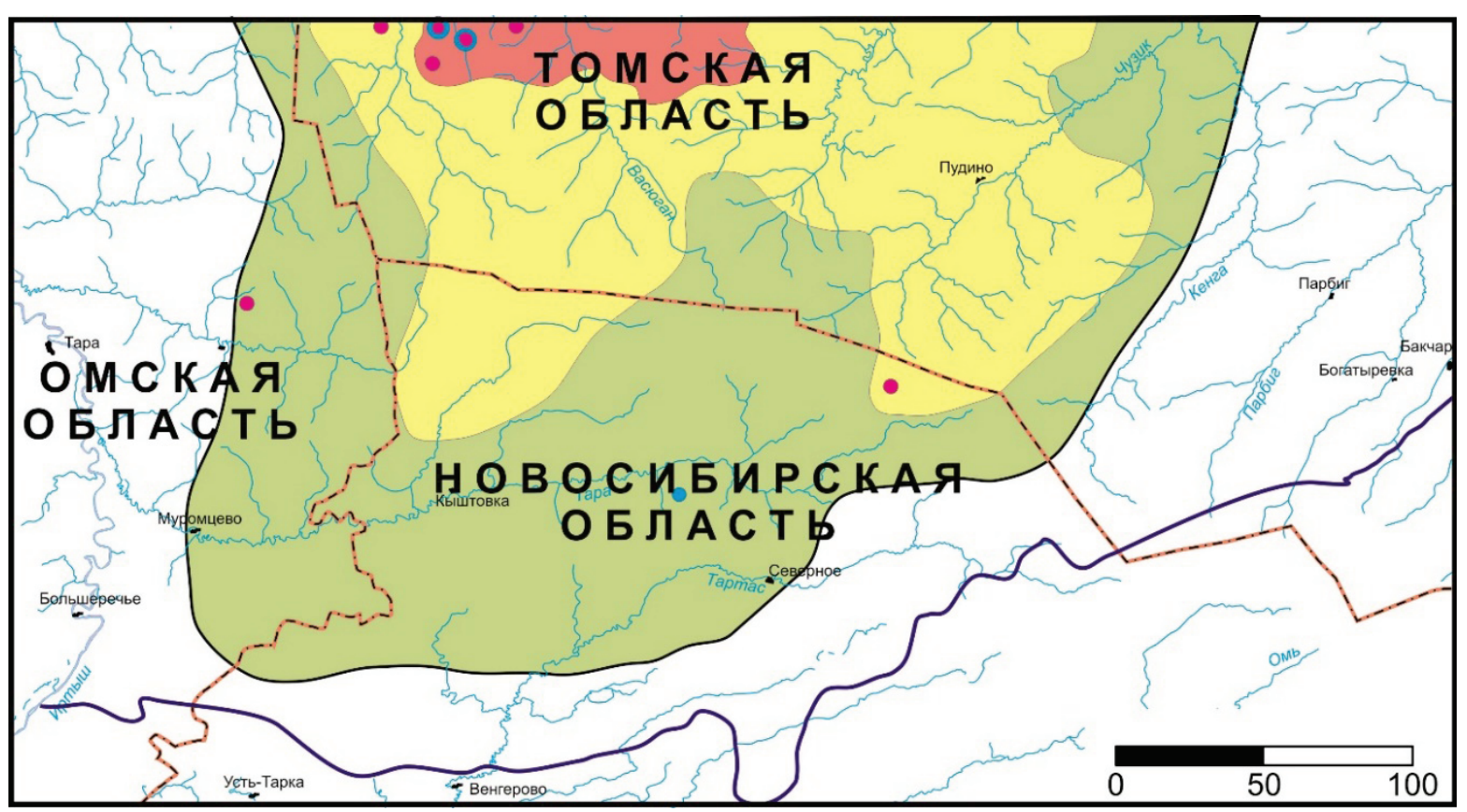

Pис. 5. Схема прогноза нефтегазоносности баженовского горизонта южных районов Западно-Сибирского бассейна. Условные обозначения с.м. рис. 2

Fig. 5. Scheme of forecasting oil-and-gas content of bazhenov formation in southern regions of the West Siberian basin. Symbols see in Fig. 2 
разведочных работ в регионе. Так, для палеозойского комплекса наиболее информативными являются гидрогеохимические показатели нефтегазоносности и анализ вещественного состава пород фундамента, для среднеюрского - гидрогеохимические и палеогеографические, для верхнеюрского - гидрогеохимические, палеогидродинамические и палеогеографические показатели. Применение данного подхода к прогнозированию существенно повысит эффективность геофизических методов при поиске новых залежей углеводородов, поскольку будет способствовать локализации геологоразведочных работ. Описанные критерии могут быть использованы также в других осадочных

\section{СПИСОК ЛИТЕРАТУРЫ}

1. Геологическое строение и полезные ископаемые Западной Сибири. Т. І. Геологическое строение / под ред. А.В. Каныгина, В.Г. Свиридова. - Новосибирск: Изд-во Сибирского отделения Российской академии наук, Научно-издательский центр Объединенного института геологии, геофизики и минералогии, 1999. -228 c.

2. Сейсмогеологические модели палеозойских комплексов и нефтегазоперспективных объектов юго-востока Западной Сибири (Новосибирская область) / В.А. Конторович, Л.М. Калинина, А.Ю. Калинин, К.И. Канакова, М.В. Соловьев // Технологии сейсморазведки. - 2017. - № 3. - С. 85-95.

3. Burnham A.K. Porosity and permeability of Green River oil shale and their changes during retorting // Fuel. - 2017. - V. 203. P. 208-213.

4. Mineralogical and morphological characterization of Older Cambay Shale from North Cambay Basin, India: Implication for shale oil/gas development / S. Kumar, S. Das, R. Bastia, K. Ojha // Marine and Petroleum Geology. - 2018. - V. 97. - P. 339-354.

5. Enrichment and distribution of shale oil in the Cretaceous Qingshankou Formation, Songliao Basin, Northeast China Ch. Liu, Z. Wang, Z. Guo, W. Hong, L. Wu // Marine and Petroleum Geology. - 2017. - V. 86. - P. 751-770.

6. Nanoscale pore structure characterization of the Bakken shale in the USA / K. Liu, M. Ostadhassan, J. Zhou, T. Gentzis, R. Rezaee // Fuel. - 2017. - V. 209. - P. 567-578.

7. Classification of microscopic pore-throats and the grading evaluation on shale oil reservoirs / S. Lu, J. Li, P. Zhang, H. Xue, Z. Li // Petroleum Exploration and Development. - 2018. - V. 45 (3). P. $452-460$.

8. Assessment of Uruguayan Oil Shales: physicochemical, thermal and morphological characterization / M. Torres, J. Castiglioni, L. Yermán, L. Suescun, A. Cuña // Fuel. - 2018. - V. 234. P. $347-357$.

9. Баженовская свита - главный источник ресурсов нетрадиционной нефти в России / А.Э. Конторович, Л.М. Бурштейн, В.А. Казаненков, В.А. Конторович, Е.А. Костырева, Е.В. Пономарева, С.В. Рыжкова, П.А. Ян // Георесурсы, геоэнергетика, геополитика: Электронный журнал. - 2014. - № 2 (10). C. $1-8$.

10. Зубков М.Ю. Региональный и локальный прогнозы нефтеносности баженовской и абалакской свит (Западная Сибирь) // Горные ведомости. - 2016. - № 3-4. - С. 46-68.

11. Девятов В.П., Сапьяник В.В., Шиганова 0.В. Ресурсный потенциал баженовского нефтеносного комплекса на юго-востоке Западной Сибири // Минеральные ресурсы России. Экономика и управление. - 2018. - № 2. - С. 18-22.

12. Костырева Е.А. Геохимия и генезис палеозойских нефтей юговостока Западной Сибири. - Новосибирск: Изд-во Сибирского бассейнах для выявления нетрадиционных залежей.

Исследование выполнено в рамках Проекта 0266-2019-0006 «Разработка методик оценки ресурсов, разведки и подсчета запасов залежей трудноизвлекаемой нефти в углеродистых карбонатно-глинисто-кремнистых, карбонатных и засолоненных песчаных коллекторах» Програмлы фундаментальных научных исследований IX.131. "Геология месторождений углеводородного сырья, фундаментальные проблемы геологии и геохимии нефти и газа, научные основы формирования сырьевой базы традиционных и нетрадиционных источников углеводородного сырья» и при финансовой поддержке РФФИ и Правительства Новосибирской области в рамках научных проектов № 17-45-543249 и 17-45-540086. отделения Российской академии наук. Филиал «ГЕО», 2005. $183 \mathrm{c.}$

13. Нефтематеринские формации Западной Сибири: старое и новое видение проблемы / А.Э. Конторович, В.П. Данилова, Е.А. Костырева, В.Р. Лившиц // Органическая геохимия нефтепроизводящих толщ Западной Сибири: матер. науч. совещ. - Новосибирск: Изд-во Сибирского отделения Российской академии наук, 1999. - С. 10-12.

14. Фомин А.Н. Катагенез органического вещества и нефтегазоносность мезозойских (юра, триас) и палеозойских отложений Западно-Сибирского мегабассейна. - Новосибирск: Институт нефтегазовой геологии и геофизики Сибирского отделения Российской академии наук, 2011. - $331 \mathrm{c}$.

15. Матусевич В.М., Попов В.К. Микроэлементы в подземных водах - показатели нефтегазоносности // Известия ВУЗов. Нефть и газ. -1978 . - № 8. - С. 3-8.

16. Назаров А.Д. Нефтегазовая гидрогеохимия юго-восточной части Западно-Сибирской нефтегазоносной провинции. - М.: Идея-Пресс, 2004. - 288 с.

17. Розин А.А. Подземные воды Западно-Сибирского артезианского бассейна и их формирование. - Новосибирск: Наука, 1977. $102 \mathrm{c.}$

18. Интерпретация результатов гидрогеологических исследований при поисках нефти и газа / М.И. Суббота, В.Ф. Клейменов, Е.В. Стадник, Л.М. Зорькин, Ю.Я. Яковлев. - М.: Недра, 1990. $-221 \mathrm{c}$.

19. Tracing enhanced oil recovery signatures in casing gases from the Lost Hills oil field using noble gases / P.H. Barry, J.T. Kulongoski, M.K. Landon, R.L. Tyne, C.J. Ballentine // Earth and Planetary Science Letters. - 2018. - V. 496. - P. 57-67.

20. Egeberg P.K., Ågaard P. Origin and evolution of formation waters from oil fields on the Norwegian shelf // Applied Geochemistry. - 1989. - V 4. - P. 131-142.

21. Evans P. Fluoride anomalies in aquifers of the Queensland sector of The Great Artesian Basin and their significance // Geological Society of Australia Abstracts. - 1996. - V. 43. - P. 172-178.

22. Hofmann H., Cartwright I. Using hydrochemistry to understand interaquifer mixing in the on-shore part of the Gippsland Basin, southeast Australia // Applied Geochemistry. - 2013. - V. 33. P. 84-103.

23. Hydrocarbon preservation conditions in Mesozoic-Paleozoic marine strata in the South Yellow Sea Basin / J. Liang, P. Zhang, J. Chen, J. Gong, Y. Yuan // Natural Gas Industry. - 2017. V. 4 (6). - P. 432-441.

24. Identifying the origin and geochemical evolution of groundwater using hydrochemistry and stable isotopes in the Subei Lake basin, Ordos energy base, Northwestern China / F. Liu, X. Song, L. Yang, Y. Zhang, D. Han, Y. Ma, H. Bu // Hydrology and Earth System Sciences. - 2015. - V. 19. - P. 551-565. 
25. Matray J.M., Fontes J.C. Origin of the oil-field brines in the Paris Basin // Geology. - 1990. - V. 18. - P. 501-504

26. Using environmental isotopes and dissolved methane concentrations to constrain hydrochemical processes and inter-aquifer mixing in the Galilee and Eromanga Basins, Great Artesian Basin, Australia / C.E. Moya, M. Raiber, M. Taulis, M.E. Cox // Journal of Hydrology. - 2016. - V. 539. - P. 304-318.

27. Novikov D.A. Theoretical substantiation of application of the hydrocarbon accumulation prospecting technique in Western Siberia based on the study of water-gas equilibria // IOP Conference Series: Earth and Environmental Science. Polar Mechanics: the Fifth All-Russian Conference with International Participation. 2018. - V. 193. - P. 012048-012048.

28. Whittemore D.0. Fate and identification of oil-brine contamination in different hydrogeologic settings // Applied Geochemistry. - 2007. - V. 22 (10). - P. 2099-2114.

29. Yao Y., Liu D., Yan T. Geological and hydrogeological controls on the accumulation of coalbed methane in the Weibei field, southeastern Ordos Basin // International Journal of Coal Geology. 2014. - V. 121. - P. 148-159.

30. Абросимова 0.0., Кулагин С.И. Выявление ловушек углеводородов неантиклинального типа в верхне-среднеюсрких отложениях (юго-восточная часть Томской области) // Известия Томского политехнического университета. - 2008. - Т. 313. № 1. - C. 51-53.

31. Палеогеография Западно-Сибирского осадочного бассейна в юрском периоде / А.Э. Конторович, В.А. Конторович, С.В. Рыжкова, Б.Н. Шурыгин, Л.Г. Вакуленко, Е.А. Гайдебурова, В.П. Данилова, В.А. Казаненков, Н.С. Ким, Е.А. Костырева, В.И. Москвин, П.А. Ян // Геология и геофизика. 2013. - T. 54. - № 8. - C. 972-1012.

32. Калинин А.Ю., Конторович В.А., Калинина Л.М. Сейсмогеологические критерии прогноза коллекторов и нефтегазоносность верхней юры юго-востока Западной Сибири // Геология нефти и газа. - 2018. - № 3. - С. 43-47.

33. Районирование мегавпадин Томской области по плотности ресурсов сланцевой нефти / В.И. Исаев, Г.А. Лобова, Е.Н. Осипо- ва, О.Г. Сургурова // Нефтегазовая геология. Теория и практика. - 2016. - T. 11. - № 1. URL: http://www.ngtp.ru/rub/4/ 1_2016.pdf (дата обращения 10.07.2019).

34. Конторович В.А. Мезозойско-кайнозойская тектоника и нефтегазоносность Западной Сибири // Геология и геофизика. 2009. - T. 50. - № 4. - C. 461-474.

35. Садыкова Я.В., Новиков Д.А. Палеогидрогеологические реконструкции верхнеюрских отложений южных районов ОбьИртышского междуречья // Известия ВУЗов. Нефть и газ. 2010. - № 1. - C. $18-25$.

36. Novikov D.A. Hydrogeochemistry of the Arctic areas of Siberian petroleum basins // Petroleum Exploration and Development. 2017. - V. 44 (5). - P. 780-786.

37. Нефтегазовая гидрогеохимия доюрских комплексов южных районов Обь-Иртышского междуречья / Д.А. Новиков, С.В. Рыжкова, Ф.Ф. Дульцев, А.В. Черных, К.В. Сесь, Н.А. Ефимцев, А.Е. Шохин // Известия Томского политехнического университета. Инжиниринг георесурсов. - 2018. T. 329. - № 12. - C. 39-54.

38. Катагенез органического вещества в кровле и подошве юрского комплекса Западно-Сибирского мегаполиса / А.Э. Конторович, А.Н. Фомин, В.О. Красавчиков, А.В. Истомин // Геология и геофизика. - 2009. - Т. 50. - № 11. - С. 1191-1200.

39. Распределение органического вещества в породах баженовского горизонта / А.Э. Конторович, Е.В. Пономарева, Л.М. Бурштейн, В.Н. Глинских, Н.С. Ким, Е.А. Костырева, М.А. Павлова, А.П. Родченко, П.А. Ян // Геология и геофизика. - 2018. T. 59. - № 3. - С. 357-371.

40. Баженовский горизонт Западной Сибири: строение, корреляция и толщины / С.В. Рыжкова, Л.М. Бурштейн, С.В. Ершов, В.А. Казаненков, А.Э. Конторович, В.А. Конторович, А.Ю. Нехаев, Б.Л. Никитенко, М.А. Фомин, Б.Л. Шурыгин, А.Л. Бейзель, Е.В. Борисов, О.В. Золотова, Л.М. Калинина, Е.В. Пономарева // Геология и геофизика. - 2018. - № 7 . C. $1053-1074$.

Поступила 14.07.2019 2.

\section{Информация об авторах}

Caдыкова Я.B., кандидат геолого-минералогических наук, старший научный сотрудник, Институт нефтегазовой геологии и геофизики Сибирского отделения Российской академии наук.

Фолин M.A., кандидат геолого-минералогических наук, научный сотрудник, Институт нефтегазовой геологии и геофизики Сибирского отделения Российской академии наук; старший преподаватель, Новосибирский национальный исследовательский государственный университет.

Pыжкова C.B., кандидат геолого-минералогических наук, старший научный сотрудник, Институт нефтегазовой геологии и геофизики Сибирского отделения Российской академии наук; старший преподаватель, Новосибирский национальный исследовательский государственный университет.

Новиков Д.А., кандидат геолого-минералогических наук, заведующий лабораторией гидрогеологии осадочных бассейнов Сибири, Институт нефтегазовой геологии и геофизики Сибирского отделения Российской академии наук; доцент, Новосибирский национальный исследовательский государственный университет.

Дульщев Ф.Ф., младший научный сотрудник, Институт нефтегазовой геологии и геофизики им. А.А. Трофимука Сибирского отделения Российской академии наук.

Черных A.B., младший научный сотрудник, Институт нефтегазовой геологии и геофизики им. А.А. Трофимука Сибирского отделения Российской академии наук. 
UDC 553.98:556.3 (571.511)

\title{
FORECAST OF OIL-AND-GAS CONTENT IN JURASSIC AND PALEOZOIC DEPOSITS OF WEST SIBERIA SOUTHERN REGIONS
}

\author{
Yana V. Sadykova', \\ SadykovaYV@ipgg.sbras.ru \\ Mikhail A. Fomin ${ }^{12}$, \\ FominMA@ipgg.sbras.ru \\ Svetlana V. Ryzhkova ${ }^{12}$, \\ RizhkovaSV@ipgg.sbras.ru \\ Dmitry A. Novikovi,2, \\ NovikovDA@ipgg.sbras.ru \\ Fedor F. Dultsev', \\ DultsevFF@ipgg.sbras.ru \\ Anatoliy V. Chernykh', \\ ChernykhAV@ipgg.sbras.ru \\ 1 Trofimuk Institute of Petroleum Geology and Geophysics Siberian Branch of Russian Academy of Sciences, \\ 3, Koptyug avenue, Novosibirsk, 630090, Russia. \\ ${ }^{2}$ Novosibirsk State University, \\ 1, Pirogov street, Novosibirsk, 630090, Russia.
}

The article is devoted to the prospects of hydrocarbon potential of the Paleozoic and Mesozoic complexes of the southern regions of Western Siberia. The problem of identifying and detailed mapping of oil-and-gas prospective objects in the southern regions of the West Siberian basin is associated with a complex nature of distribution of the reservoirs and their spatial relationships with impermeable rocks, which predetermines location of oil and gas deposits at complex non-anticlinal traps. To identify them, it is necessary to apply an integrated method of forecasting, which includes, in addition to the tectonic, lithological and stratigraphic studies of the enclosing rocks, hydrogeological ones as well. The application of hydrogeological criteria for regional, zonal and local assessment of petroleum potential is based on the large role of ground waters in oil-and-gas formation. We have established the hydrogeochemical features of ground waters, identified hydrogeochemical anomalies closely related to hydrocarbon accumulations $\left(\mathrm{I}, \mathrm{B}, \mathrm{Br}, \mathrm{NH}_{4}\right.$ etc.). The genetic types of ground waters and degree of their catagenetic maturation are characterized. We have presented the results of paleohydrogeochemical and paleohydrodynamic reconstructions, selected the most probable zones of hydrocarbon generation and accumulation, outlined the main routes of fluid migration. We have studied features of the geological structure and allocated zones of the improved collectors development. A set of somewhat differing criteria of oil-and-gas content for Paleozoic, Middle and Upper Jurassic complexes were justified on the bases of hydrogeological and geological indicators. Based on the suggested complex of criteria, forecast of oil-and-gas content was carried out and sites of various categories of prospects (lands highly-perspective, perspective and without clear prospects demanding further studying) were marked. Application of this approach will promote localization of exploration works and increase efficiency of geophysical methods in search of new deposits of hydrocarbons in the southern regions of the West Siberian basin.

\section{Key words:}

Southern regions of the West Siberian basin, hydrogeology, hydrogeochemistry,

hydrocarbon potential, Jurassic and Paleozoic complexes

The research was carried out within the project 0266-2019-0006 «Development of techniques to assess resources, explore and calculate the reserves of unconventional oil accumulations in carbon carbonate-siliceous-argillaceous, carbon-bearing and saline sand reservoirs» of the Program of fundamental scientific researches «Geology of hydrocarbon material deposits, fundamental problems of geology and geochemistry of oil and gas, scientific bases of forming raw material base of conventional and unconventional sources of hydrocarbon material». The research was financially supported by the RFBR and the Administration of Novosibirsk region within the scientific projects no. 17-45-543249 and 17-45-540086.

\section{REFERENCES}

1. Geologicheskoe stroenie i poleznye iskopaemye Zapadnoy Sibiri [Geological structure and mineral resources of Western Siberia]. T. I. Geologicheskoe stroenie [Vol. I. Geological structure]. Eds. A.V. Kanygin, V.G. Sviridov. Novosibirsk, Siberian Branch of the Russian Academy of Sciences Publ. House, 1999. 228 p.

2. Kontorovich V.A., Kalinina L.M., Kalinin A.Yu., Kanakova K.I., Solovev M.V. Seismological models of Paleozoic complexes and oil and gas perspective objects in the south-east of Western Siberia (Novosibirsk region). Seismic technology, 2017, no. 3, pp. 85-95. In Rus.

3. Burnham A.K. Porosity and permeability of Green River oil shale and their changes during retorting. Fuel, 2017, vol. 203, pp. 208-213.

4. Kumar S., Das S., Bastia R., Ojha K. Mineralogical and morphological characterization of Older Cambay Shale from North Cam- 
bay Basin, India: Implication for shale oil/gas development. $\mathrm{Ma}$ rine and Petroleum Geology, 2018, vol. 97, pp. 339-354.

5. Liu Ch., Wang Z., Guo Z., Hong W., Wu L. Enrichment and distribution of shale oil in the Cretaceous Qingshankou Formation, Songliao Basin, Northeast China. Marine and Petroleum Geology, 2017, vol. 86, pp. 751-770.

6. Liu K., Ostadhassan M., Zhou J., Gentzis T., Rezaee R. Nanoscale pore structure characterization of the Bakken shale in the USA. Fuel, 2017, vol. 209, pp. 567-578.

7. Lu S., Li J., Zhang P., Xue H., Li Z. Classification of microscopic pore-throats and the grading evaluation on shale oil reservoirs. Petroleum Exploration and Development, 2018, vol. 45 (3), pp. $452-460$.

8. Torres M., Castiglioni J., Yermán L., Suescun L., Cuña A. Assessment of Uruguayan Oil Shales: physicochemical, thermal and morphological characterization. Fuel, 2018, vol. 234, pp. 347-357.

9. Kontorovich A.E., Burshteyn L.M., Kazanenkov V.A., Kontorovich V.A., Kostyreva E.A., Ponomareva E.V., Ryzhkova S.V., Yan P.A. The Bazhenov formation is the main source of unconventional oil in Russia. Georesources, geoenergy, geopolitics: Elec tronic journal, 2014, no. 2 (10), pp. 1-8. In Rus.

10. Zubkov M.Yu. Regional and local oil-bearing forecasts of the Bazhenov and Abalak Formations (Western Siberia). Mining jour nal, 2016, no. 3-4, pp. 46-68. In Rus.

11. Devyatov V.P., Sapyanik V.V., Shiganova O.V. Resource potential of the Bazhenov oil complex in the south-east of Western Siberia. Mineral resources of Russia. Economics and Management, 2018, no. 2, pp. 18-22. In Rus.

12. Kostyreva E.A. Geokhimiya $i$ genezis paleozoyskikh neftey yugovostoka Zapadnoy Sibiri [Geochemistry and genesis of Paleozoic oil in southeast of the Western Siberia]. Novosibirsk, Siberian Branch of the Russian Academy of Sciences Publ. House, 2005. $183 \mathrm{p}$.

13. Kontorovich A.E., Danilova V.P., Kostyreva E.A., Livshits V.R. Neftematerinskie formatsii Zapadnoy Sibiri: staroe i novoe videnie problem [0il source formations of Western Siberia: old and new vision of the problem]. Organicheskaya geokhimiya nefteproizvodyashchikh tolshch Zapadnoy Sibiri. Materialy nauchnogo soveshchaniya [Organic geochemistry of oil producing strata in Western Siberia. Scientific meeting Proc.]. Novosibirsk, Siberian Branch of the Russian Academy of Sciences Publ. House, 1999. pp. 10-12.

14. Fomin A.N. Katagenez organicheskogo veshchestva i neftegazonosnost mezozoyskikh i paleozoyskikh otlozheniy Zapadno-Sibirskogo megabasseyna [Catagenesis of organic matter and oil-andgas of the Mesozoic and Paleozoic deposits of the Western Siberian megabasin]. Novosibirsk, Institute of petroleum geology and geophysic Siberian Branch of the Russian Academy of Sciences Publ. House, 2011. 331 p.

15. Matusevich V.M., Popov V.K. Mikroelementy v podzemnykh vodakh - pokazateli neftegazonosnosti [Trace elements in groundwater as oil and gas indicators]. Izvestiya VUZov. Neft $i$ gaz, 1978, no. 8, pp. 3-8.

16. Nazarov A.D. Neftegazovaya gidrogeokhimiya yugo-vostochnoy chasti Zapadno-Sibirskoy neftegazonosnoy provintsii [0il and gas hydrogeochemistry of the south-eastern part of the West Siberian oil and gas province]. Moscow, Ideya-Press Publ., 2004. 288 p.

17. Rozin A.A. Podzemnye vody Zapadno-Sibirskogo artezianskogo basseyna i ikh formirovanie [Groundwaters of the West Siberian artesian basin and their formation]. Novosibirsk, Nauka Publ., 1977. $102 \mathrm{p}$.

18. Subbota M.I., Kleymenov V.F., Stadnik E.V., Zorkin L.M., Yakovlev Yu.Ya. Interpretatsiya rezultatov gidrogeologicheskikh issledovaniy pri poiskakh nefti i gaza [Interpretation of the results of hydrogeological studies in prospecting for oil and gas.]. Moscow, Nedra Publ., 1990. 221 p.
19. Barry P.H., Kulongoski J.T., Landon M.K., Tyne R.L., Ballentine C.J. Tracing enhanced oil recovery signatures in casing gases from the Lost Hills oil field using noble gases. Earth and Planetary Science Letters, 2018, vol. 496, pp. 57-67.

20. Egeberg P.K., Ågaard P. Origin and evolution of formation waters from oil fields on the Norwegian shelf. Applied Geochemistry, 1989, vol. 4, pp. 131-142.

21. Evans P. Fluoride anomalies in aquifers of the Queensland sector of The Great Artesian Basin and their significance. Geological Society of Australia Abstracts, 1996, vol. 43, pp. 172-178.

22. Hofmann H., Cartwright I. Using hydrochemistry to understand interaquifer mixing in the on-shore part of the Gippsland Basin, southeast Australia. Applied Geochemistry, 2013, vol. 33, pp. 84-103.

23. Liang J., Zhang P., Chen J., Gong J., Yuan Y. Hydrocarbon preservation conditions in Mesozoic-Paleozoic marine strata in the South Yellow Sea Basin. Natural Gas Industry, 2017, vol. 4 (6), pp. 432-441.

24. Liu F., Song X., Yang L., Zhang Y., Han D., Ma Y., Bu H., Identifying the origin and geochemical evolution of groundwater using hydrochemistry and stable isotopes in the Subei Lake basin, Ordos energy base, Northwestern China. Hydrology and Earth System Sciences, 2015, vol. 19, pp. 551-565.

25. Matray J.-M., Fontes J.-C. Origin of the oil-field brines in the Paris Basin. Geology, 1990, vol. 18, pp. 501-504.

26. Moya C.E., Raiber M., Taulis M., Cox M.E. Using environmental isotopes and dissolved methane concentrations to constrain hydrochemical processes and inter-aquifer mixing in the Galilee and Eromanga Basins, Great Artesian Basin, Australia. Journal of Hydrology, 2016, vol. 539, pp. 304-318.

27. Novikov D.A. Theoretical substantiation of application of the hydrocarbon accumulation prospecting technique in Western Siberia based on the study of water-gas equilibria. IOP Conference Series: Earth and Environmental Science. The Fifth All-Russian Conference with International Participation. Polar Mechanics, 2018, vol. 193, pp. 012048-012048.

28. Whittemore D.0. Fate and identification of oil-brine contamination in different hydrogeologic settings. Applied Geochemistry, 2007, vol. 22 (10), pp. 2099-2114.

29. Yao Y., Liu D., Yan T. Geological and hydrogeological controls on the accumulation of coalbed methane in the Weibei field, southeastern Ordos Basin. International Journal of Coal Geology, 2014, vol. 121, pp. 148-159.

30. Abrosimova 0.0., Kulagin S.I. Revealing of traps of the non-anticlinal type of hydrocarbons in Upper-, Middle-Jurassic deposits (southeast part of Tomsk oblast). Bulletin of the Tomsk Polytechnic University, 2008, vol. 313, no. 1, pp. 51-53. In Rus.

31. Kontorovich A.E., Kontorovich V.A., Ryzhkova S.V., Shurygin B.N., Vakulenko L.G., Gaydeburova E.A., Danilova V.P., Kazanenkov V.A., Kim N.S., Kostyreva E.A., Moskvin V.I., Yan P.A. Jurassic paleogeography of the West Siberian sedimentary basin. Russian Geology and Geophysics, 2013, vol. 54, no. 8, pp. 747-779.

32. Kalinin A.Yu., Kontorovich V.A., Kalinina L.M. Seismological criteria for the forecast of reservoirs and the oil and gas content of the Upper Jurassic in the south-east of Western Siberia. Oil and Gas Geology, 2018, no. 3, pp. 43-47. In Rus.

33. Isaev V.I., Lobova G.A., Osipova E.N., Surgurova 0.G. Zoning of mega depressions of the Tomsk region according to the density of shale oil resources. Oil and gas geology. Theory and practice, 2016, vol. 11, no. 1, pp. 1-21. In Rus. Available at: http://www. ngtp.ru/rub/4/1_2016.pdf (accessed 10 July 2019).

34. Kontorovich V.A. The Meso-Cenozoic tectonics and petroleum potential of West Siberia. Russian Geology and Geophysics, 2009, vol. 50, no. 4, pp. 346-357.

35. Sadykova Ya.V., Novikov D.A. Paleontological reconstructions of the Upper Jurassic sediments of the southern regions of the Ob- 
Irtysh interfluve. The journal «Oil and Gas Studies», 2010, no. 1, pp. 18-25. In Rus.

36. Novikov D.A. Hydrogeochemistry of the Arctic areas of Siberian petroleum basins. Petroleum Exploration and Development, 2017, vol. 44 (5), pp. 780-786.

37. Novikov D.A., Ryzhkova S.V., Dultsev F.F., Chernykh A.V., Ses K.V., Efimtsev N.A., Shokhin A.E. Oil and gas hydrogeochemistry of pre-Jurassic complexes of the southern regions of the Ob-Irtysh interfluve. Bulletin of the Tomsk Politechnic University. Geo Assets Engineering, 2018, vol. 329, no. 12, pp. 39-54.

38. Kontorovich A.E., Fomin A.N., Krasavchikov V.O., Istomin A.V. Catagenesis of organic matter at the top and base of the Jurassic complex in the West Siberian megabasin. Russian Geology and Geophysics, 2009, vol. 50, no. 11, pp. 917-929.
39. Kontorovich A.E., Ponomareva E.V., Burshteyn L.M., Glinskikh V.N., Kim N.S., Kostyreva E.A., Pavlova M.A., Rodchenko A.P., Yan P.A. Distribution of organic matter in rocks of the Bazhenov horizon (West Siberia). Russian Geology and Geophysics, 2018, vol. 59, no. 3, pp. 285-298.

40. Ryzhkova S.V., Burshteyn L.M., Ershov S.V., Kazanenkov V.A., Kontorovich A.E., Kontorovich V.A., Nekhaev A.Yu., Nikitenko B.L., Fomin M.A., Shurygin B.L., Bejzel A.L., Borisov E.V., Zolotova 0.V., Kalinina L.M., Ponomareva E.V. The Bazhenov Horizon of West Siberia: structure, correlation, and thickness. Russian Geology and Geophysics, 2018, vol. 59, no. 7, pp. $846-863$.

Received: 14 July 2019.

\section{Information about the authors}

Yana V. Sadykova, Cand. Sc., senior researcher, Trofimuk Institute of Petroleum Geology and Geophysics Siberian Branch of Russian Academy of Sciences.

Mikhail A. Fomin, Cand. Sc., researcher, Trofimuk Institute of Petroleum Geology and Geophysics Siberian Branch of Russian Academy of Sciences; senior lecturer, Novosibirsk State University.

Svetlana V. Ryzhkova, Cand. Sc., senior researcher, Trofimuk Institute of Petroleum Geology and Geophysics Siberian Branch of Russian Academy of Sciences; senior lecturer, Novosibirsk State University.

Dmitry A. Novikov, Cand. Sc., head of the laboratory, Trofimuk Institute of Petroleum Geology and Geophysics Siberian Branch of Russian Academy of Sciences; assistant professor, Novosibirsk State University.

Fedor F . Dultsev, junior researcher, Trofimuk Institute of Petroleum Geology and Geophysics Siberian Branch of Russian Academy of Sciences.

Anatoliy V. Chernykh, junior researcher, Trofimuk Institute of Petroleum Geology and Geophysics Siberian Branch of Russian Academy of Sciences. 